\title{
Mechanisms of Vasodilatation
}

\section{Abstracts}

Editor:

P.M. Vanhoutte, Rochester, Minn.

mum

S. Karger $\cdot$ Medical and Scientific Publishers

Basel · München · Paris · London · New York · New Delhi · Singapore · Tokyo · Sydney

Drug Dosage

The authors and the publisher have exerted every effort to ensure that drug selection and dosage set forth in this text are in accord with current recommendations and practice at the time of publication. However, in view of ongoing research, changes in government regulations, and the constant flow of information relating to drug therapy and drug reactions, the reader is urged to check the package insert for each drug for any change in indications and dosage and for added warnings and precautions. This is particularly important when the recommended agent is a new and/or infrequently employed drug.

All rights reserved.

No part of this publication may be translated into other languages, reproduced or utilized in any form or by any means, electronic or mechanical, including photocopying, recording, microcopying, or by any information storage and retrieval system, without permission in writing from the publisher or, in the case of photocopying, direct payment of a specified fee to the Copyright Clearance Center (see 'Information for Readers and Subscribers').

(C) Copyright 1986 by

S. Karger AG, P.O. Box, CH-4009 Basel (Switzerland) Printed in Switzerland by Thiir AG OfT setdruck, Pratteln ISBN 3-8055^*361-1 